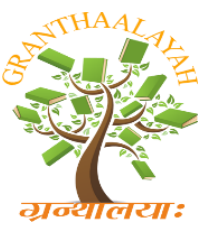

INTERNATIONAL JOURNAL OF RESEARCH GRANTHAALAYAH A knowledge Repository

\title{
REMOVAL OF TURBIDITY IN DAIRY WASTE WATER THROUGH AQUATIC MACROPHYTES
}

\author{
R. Bhutiani, D.R. Khanna, Varun Tyagi, Faheem Ahamad \\ Dept. of Zoology \& Environmental Sciences, Gurukula Kangri Vishwavidyalaya, Haridwar
}

\begin{abstract}
Demand for milk and milk products caused vast growth of dairy industries in most countries of the world. Consequently, the amount of wastewater and waste material generated and discharged from these industries has also increased. Phytoremediation provides eco-friendly, low cost treatment approach for the waste water treatment. In the current study aquatic macrophytes Eichornia and Lemna were taken in account individually and in combination. A wetland approach was used for the treatment of effluent (waste water) from Parag Dairy and Milk processing plant, Meerut. Effluent was then transferred to glass aquarium and analysed for Physico-chemical parameters viz. Temp., $\mathrm{pH}$, Turbidity. The initial parameters of the raw waste water were recorded Temp $25.34^{\circ} \mathrm{C}$, pH 5.8, Turbidity 648 NTU. After the treatment, $75 \%$ removal of turbidity was recorded in case of Eichornia (486 NTU), while Lemna showed a potential of $54 \%$ removal (350 NTU) of turbidity. Keywords:

Eichornia, Lemna, dairy waste water, phytoremediation, turbidity.
\end{abstract}

\section{INTRODUCTION}

Industrial development and explosion of population are the primary reasons for the dwindling water quality as the pollutant load is increasing day by day in the water bodies. The dairy industry is one of the most polluting of industries, it generates about 0.2-10 litres of effluent per litre of processed milk (Vourch et al., 2008). Such wastewaters and waste material, if discharged without proper treatment, severely pollute receiving water bodies. The minimization of waste and reductions in material and energy inputs are the most important environmental aims. Aquatic plants play an important role in structural and functional aspects of aquatic ecosystems by various ways and phytoremediation is one of them. Phytoremediation includes the use of plants as well as microorganisms of the rhizosphere to remove or render harmless pollutants from contaminated sites (Lasat, 2002). Waste water treatment with culture of aquatic macrophytes such as Eichornia, Pistia, Lemna, Typha etc. for the purpose of pollution abatement has received growing acceptance (Swati et al., 2011).

\section{MATERIALS AND METHODS}

Experimental plants: The plants used for the study included floating wetland macrophytes Lemna and Eichhornia were collected from local pond. Roots were thoroughly washed with running tap water. Water hyacinth (Eichhornia crassipus) belongs to the family Pontederiaceae with axillary leaves, appearing to develop in rosettes, with long or short petioles. Lemna is a genus of free- 
floating aquatic plants from the duckweed family. The duckweeds have been classified as a separate family, the Lemnaceae, but some researchers consider the duckweeds members of the Araceae. The plants grow mainly by vegetative reproduction. The experimental plants were initially subject to stabilization in glass aquariums containing tap water for 15 days for acclimatization. Twenty litres of the effluent were prepared (one without dilution and the other with 50\% dilution) and then transferred to glass aquariums. For each experimental set, two controls were maintained with 101 of tap water and 101 of raw effluent, respectively. For treatments, the plants which maintained in the stock tanks were collected, cleaned and introduced in the experimental tanks.

\section{EXPERIMENTAL DESIGN}

Four glass aquariums of same dimension $(20 \times 20 \times 25 \mathrm{~cm})$ were used for each plant. Approximately $250 \mathrm{~g}$ (wet weight) of each experimental plant is used for the study, each occupying half of the glass aquariums. The number of plants varied in case of Eichornia and Lemna; for example, in case of Eichhornia sp. more than five plants were used whereas Lemna being shorter and less extensive root shoot system included more than 100 plants. Experiments were conducted in individual and in combination including both Eichornia and Lemna. Duplicate of each experimental setup was maintained. A volume of $200 \mathrm{ml}$ each of water and effluent from the respective treatment sets were collected periodically for analysing the changes in its physicochemical characteristics subsequently with an interval of 5 days up to 20 days. Thus, the analyses of water samples were carried out at four stages of treatment at initial level and subsequently at 5 days, 15 days, and 20 days. The setup was same for all the treatments. The effluent samples collected from the treatment sets were subjected to physico-chemical analysis following standard methods. Major parameters analysed include $\mathrm{pH}$, turbidity, conductivity, total solids for the period of six months.

\section{RESULTS AND DISCUSSION}

For a phytoremediation system to work efficiently, optimal plant growth is the key parameter. Many environmental factors can influence plant growth and its performance, such as temperature, $\mathrm{pH}$, solar radiation, and salinity of the water. The weight and size of aquatic plants are a function of these factors (US EPA Design Manual, 1988). Its growth can be described by two ways: first by reporting the percentage of water surface covered for a period of time and second but more useful is by reporting the plant density in units of wet plant mass per unit of surface area (Lissy and Madhu, 2010). When treated with Eichhornia sp., Turbidity was found to decrease in undiluted effluent (75.04\%), from initial turbidity of 648.15 NTU to 486 NTU. After dilution, turbidity decreased $(59.78 \%)$ during the treatment period, pronounced reduction in both diluted and undiluted effluents in the Eichhornia sp.-based treatment was observed. Lu et al. (2010), Trivedy and Pattanshetty (2002) showed that the growth decreased the EC in the treatment plot due to salt removal from the waters by plant uptake or root adsorption and it was concluded that water quality in ponds was improved by phytoremediation with water lettuce, as evidenced by decreased turbidity. However on treatment with Lemna sp., Turbidity showed a decreasing trend in undiluted effluent, i.e., 648 NTU-350 NTU (54\%). Dipu et al., (2011) also observed similar trend in the removal capacity of free floating macrophytes. Among the both floating macrophytes, Eichhornia sp. was found to be more effective. The extensive root system played a major role in the reduction of the turbidity of the waste water. 


\section{CONCLUSION}

Phytoremediation can be an important approach for cleaning waste waters from dairy sector where pollution load typically includes organic matter. It has been observed that phytoremediation of wastewater using the floating plant system is a predominant method which is economic to construct and requires little maintenance and increase the biodiversity. Treatment capabilities depend on different factors like climate, contaminants of different concentrations, temperature, etc. The removal efficiency of contaminants like TSS, TDS, EC, etc. varies from plant to plant. Plant growth rate and hydraulic retention time can influence the reduction of contaminants. Therefore, an available knowledge and techniques for removal of water contaminants and advances in waste water treatment can be integrated to assess and control water pollution.

\section{REFERENCES}

1. Dipu, S., Kumar, A.A and Thanga, V.S.G., 2011, Phytoremediation of dairy effluent by constructed wetland technology, Environmentalist, 31, 263-278.

2. Lasat MM (2002) Phytoextraction of toxic metals: a review of biological mechanisms. $J$ Environ Qual 31:109-129

3. Lissy, A.M.P.N, and Madhu, B.Dr.G., 2010, Removal of heavy metals from waste water using water hyacinth., In: Proc. of the International Conference on Advances in Civil Engineering, 42-47.

4. Lu, Q., He, Z.L., Graetz, D.A., Stoffella, P.J. and Yan g, X., 2010, Phytoremediation to remove nutrients and improve eutrophic stormwaters using water lettuce (Pistia stratiotes L.)., Environ. Sci. Pol l. Res., 17, 84-96.

5. Swati Bhavsar, Vedavati Pujari, Dr. V.V. Diwan Potential of Phytoremediation for dairy Waste Water Treatment. (2011) pp.16-23.

6. Trivedy, R.K. and Pattanshetty, S.M., 2002, Treatment of dairy waste by using water hyacinth., Water Sci. Technol., 45(12), 329-334.

7. USEPA, 1988, Design Manual - Constructed wetlands and aquatic systems for municipal wastewater treatment, United States Environmental Protection Agency, Report no. EPA/625/1-88/022, Office of Research and Development, Cincinnati, OH, 83.

8. Vourch, M. Balannec, B., Chaufer, B., and Dorange, G., Treatment of dairy industry wastewater by reverse osmosis for water reuse, Desalination, Elsevier, 219(2008), pp.190202. 